\title{
Quantitative changes in the otolithic organs of the inner ear during the settlement period in European hake Merluccius merluccius
}

\author{
Antoni Lombarte ${ }^{1, *}$, Arthur N. Popper ${ }^{2}$ \\ ${ }^{1}$ Institut de Ciències del Mar (CMIMA-CSIC), Passeig Marítim 37-49, 08003 Barcelona, Catalonia, Spain \\ ${ }^{2}$ Department of Biology \& Neuroscience and Cognitive Science Program, University of Maryland, \\ College Park, Maryland 20742, USA
}

\begin{abstract}
Qualitative and quantitative observations were made of the density and growth of the sensory epithelia, hair cell number, and otoliths of the 3 pairs of end organs (saccule, lagena, and utricle) of the inner ear of European hake Merluccius merluccius (35 to $100 \mathrm{~mm}$ length) caught in the northwestern Mediterranean Sea. This is the period in the hake's life-history during which the transition from pelagic to epibenthic forms (settlement period) occurs. The results demonstrate a quantitative inversion in the percentage of the sensory epithelia area and the number of hair cells between the saccule and utricle over this time period. This period is also coincident with the settlement period that takes place when most individuals are ca. $50 \mathrm{~mm}$, at which time the fish become epibenthic. These quantitative changes in the ear could be related to ecological changes in mobility and feeding.
\end{abstract}

KEY WORDS: Ecomorphology · Inner ear · Sensory hair cells · Otolith · Merluccis merluccius

\section{INTRODUCTION}

Comparative studies of organisms' morphological features, and their relationship to the environment and its changes, are important for understanding the interactions between them (Ricklefs \& Miles 1994, Norton et al. 1995). Moreover, the study of sense-organ morphology is essential in the explanation of the mechanisms that regulate animal distribution during ontogeny (Blaxter 1988).

Fishes, like all other vertebrates, gain a great deal of information about their environment by listening to background noises, particularly when they come from beyond the visual range of the animal (Fay \& Popper 2000, Popper et al. 2003). This information may be in the form of sounds of predators or prey, or may be other environmental sounds such as waves, reflections of energy from the bottom, or the sounds of a coral reef. Although not demonstrated in any studies to date, it may be hypothesized that develop- mental changes might occur in the auditory system of a fish as it takes up life in new habitats (Norton et al. 1995).

One fish species that would allow testing of this hypothesis is the European hake Merluccius merluccius, a member of the order Gadiformes. Merluccius shows substantial changes in lifestyle during the time between hatching and reaching the age at which the species is commercially important (Recasens et al. 1998). Presumably, some of the changes that the fish undergo as they mature include adjustments in their ability to detect sensory signals as they change lifestyles.

Supporting this suggestion are the results from an earlier study in which we demonstrated that as hake grew from 100 to over $750 \mathrm{~mm}$, they also showed substantial changes in the size of the ear, including the number of sensory hair cells (Lombarte \& Popper 1994). Although we could not do behavioral studies on hearing in this species, the increase in the number of 
sensory hair cells, the transducing element of the inner ear, went from ca. $50000 \mathrm{ear}^{-1}$ in fishes that were $100 \mathrm{~mm}$ total length, to over 2 million ear ${ }^{-1}$ in fish that were ca. $9 \mathrm{yr}$ of age and just over $750 \mathrm{~mm}$ in total length. In particular, the saccule, the major end organ of the ear involved with hearing, showed the most substantial increase in hair cell number, leading us to suggest that the increase may be related to changes in the ecology and behavior of hake as they moved to depths as great as $800 \mathrm{~m}$ (Lombarte \& Popper 1994, Recasens et al. 1998).

More recent data support the hypothesis that the changes in the size of the ear may be correlated with ecology and behavior. Studies on the feeding ecology of Merluccius merluccius (Guichet 1995, Bozzano et al. 1997) suggest a very different diet in fish of different sizes. Larvae and the earliest pelagic juveniles have a maximum vertical density of 50 to $60 \mathrm{~m}$ in depth (Olivar \& Sabatés 1997, Motos et al. 2000, Olivar et al. 2003). Pelagic larvae of various Merluccius species are zooplanktivorous, and prey and predators can potentially be found all around the larvae (Cass-Calay 2003). Once the fish reach 40 to $50 \mathrm{~mm}$ in total length, they go to the bottom (Arneri \& Morales-Nin 2000, Lleonart 2001, Maynou et al. 2003) and live at depths from 100 to $200 \mathrm{~m}$ (Recasens et al. 1998). Concurrently, the fish become benthic feeders and consume small crustaceans that live associated with the bottom (Bozzano et al. 1997, Lleonart 2001). After fish reach $200 \mathrm{~mm}$ in length, their diet is composed of various fishes, with the major food source being other gadiform species such as Micromesisitius poutassou or Trisopterus minutus, and clupeiforms such as anchovy Engraulis encrassicolus and Sardina pilchardus. The largest specimens of $M$. merluccius in Atlantic waters also feed on the carangid Trachurus trachurus, and myctophids are also a minor prey.

Although our earlier work involved hake after their settlement period, it is possible that the transition from pelagic postlarval to epibenthic (or demersal) juvenile forms also show changes in ear structure as they develop and inhabit different ecological niches and change their feeding habits. Thus, the purpose of this study was to investigate changes in the end organs of the ear associated with hearing in fishes during the period of transition from pelagic to epibenthic forms. It is clear that the period of time in the life of European hake studied here includes the time in which they undergo the largest changes in their life history, including in habitat, feeding resources, and behavior (Olivar \& Sabatés 1997). We therefore hypothesize that morphological changes observed in this period should be correlated with adaptations from pelagic to epibenthic environments.

\section{MATERIALS AND METHODS}

Analysis of sensory hair cells of the inner ear was done on 9 European hake Merluccius merluccius that were $35,45,50,55,60,75,80,95$, and $100 \mathrm{~mm}$ in total length, a size range that corresponds to ages of 50 to 200 d (Arneri \& Morales-Nin 2000). The specimens were collected in oceanographic vessels in the Catalan Sea (northwestern Mediterranean) at depths between 100 and $200 \mathrm{~m}$ (Lleonart 2001). All the fish were dead either when they arrived at the surface or shortly after, and most were dead for several minutes before they could be fixed and prepared for study. In order to fix the tissue, the heads were opened and the otic endorgans were exposed and fixed in $2.5 \%$ gluteraldehyde in $0.2 \mathrm{M}$ phosphate buffer. Additional fixative was injected into the otic capsule to improve fixation. Afterward, sensory epithelia of the inner ears of each specimen were removed and prepared for scanning electron microscopy (SEM) using methods similar to those described earlier (Lombarte \& Popper 1994). The samples were mounted flat on aluminum stubs, coated with gold, and viewed with a HITACHI S 570 SEM operating at $15 \mathrm{kV}$.

It was not possible to count all the hair cell ciliary bundles in a single epithelium because the number was very high in larger specimens. Consequently, we counted the number of ciliary bundles in selected areas of each end organ and then used these values to estimate the total number of ciliary bundles in each end organ. The same regions of each end organ were sampled in all specimens (Fig. 1). These regions were identified in each end organ by establishing general physical landmarks (e.g. points of curvature, bends). Twelve regions were sampled from the saccule, 6 from the utricle, and 5 from the lagena (Fig. 1). In the utricle and lagena, 2 samples were taken from the striolar region of the epithelium, a morphologically differentiated central

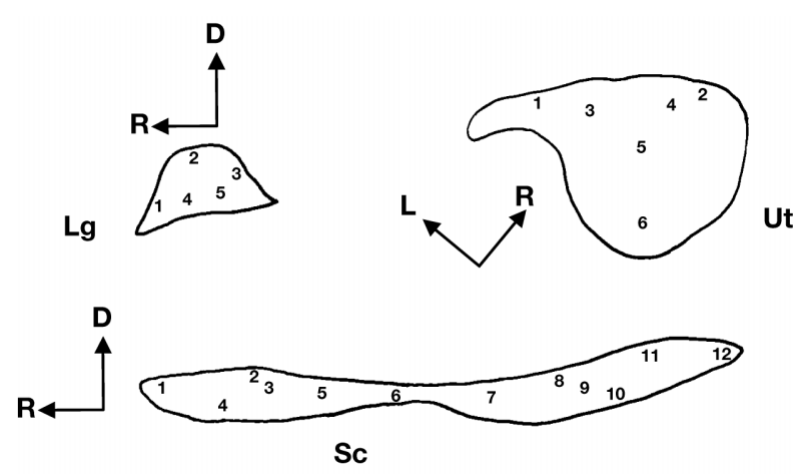

Fig. 1. Merluccius merluccius. Drawings of the 3 end organs from the left inner ear. Numbers indicate the different sites photographed in each epithelium for counts of sensory hair cells. Lg: lagena; Sc: sacculus; Ut: utricle; D: dorsal site; R: rostral side; L: lateral side 
area of both end organs (Lombarte et al. 1993). The density values were used to estimate the total number of hair cells per end organ. These data were used to calculate the density, in number of hair cells per $1000 \mu^{2}$, as in our earlier study (Lombarte \& Popper 1994).

The selected regions were photographed at $3000 \times$, representing an area that was $31 \times 33 \mu \mathrm{m}$. All the hair cells in each photograph were counted (Lombarte \& Popper 1994).

The area of each sensory epithelium divided by the area of their corresponding otolith (M:O ratio) was also calculated for every end organ studied. The areas of sensory epithelia and otoliths were measured by the OPTIMAS digital processing system from low-power SEM photographs.

The morphometric relationships between different characters of the inner ear (density of ciliary bundles, number of bundles, otolith area, and epithelium) and fish body length were determined by fitting a power equation $y=a x^{b}$, where $a$ is $x$ coefficient and $b$ is slope. A Student's $t$-test was used to compare slopes $(b)$ of the morphometric relationships with hypothetical values of isometry. The confidence limits for parameter $b$ were calculated for the $95 \%$ level of significance.

\section{RESULTS}

\section{Inner ear morphology}

The shape of the ear (Fig. 1), sensory epithelia, and hair-cell orientation patterns (Fig. 2) are very similar to the late juveniles and adults described by Lombarte \& Popper (1994). The hair-cell orientation patterns on the utricle and lagena are very similar across the size classes used in this study. Only minor differences were observed in the saccular epithelium, although, like adult species, the orientation pattern of even the smallest fish studied is organized in the typical dual pattern found in gadiform fishes (Popper \& Coombs 1982). In the smaller individuals, the sizes of the rostral area and caudal areas of the saccular macula are very similar to one another, and the narrow central area dividing them is also very short. The second difference was an increase in the proportion of horizontally oriented cells in relation to vertically oriented cells compared with that in the larger individuals.

\section{Hair cell density}

The 3 end organs differed from one another in the density of their ciliary bundle (Fig. 3), although there were no statistically different densities within any single end organ. The highest density was found in the

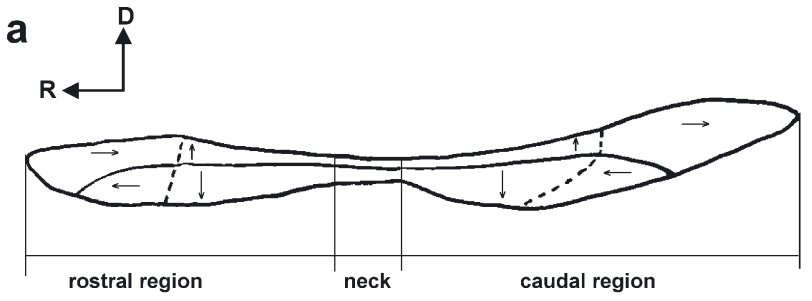

b

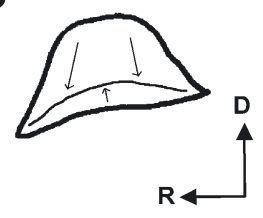

C

$\mathbf{L}$

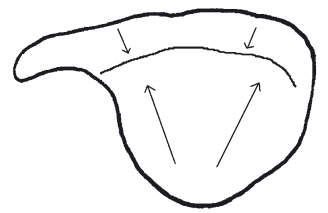

Fig. 2. Merluccius merluccius. Orientation patterns of the ciliary bundles on sensory hair cells of macular areas in a $35 \mathrm{~mm}$ fish. (a) Left saccule, (b) left lagena, (c) left utricle. Arrows indicate polar orientation of the ciliary bundles from stereocilia to kinocilia. Solid lines indicate the point at which there is an abrupt shift in orientation between ciliary bundle groups. Dashed lines show the general region in which there is a gradual shift in orientation within a ciliary bundle group. D: dorsal side; R: rostral side; L: lateral side

lagena (between 73 and 106 hair cells per $1000 \mu \mathrm{m}^{2}$ ) and the utricle (between 68 and 107 hair cells per $1000 \mathrm{\mu m}^{2}$ ), whereas the saccule had the lowest density (between 50 and 73 hair cells $1000 \mu \mathrm{m}^{2}$ ). A density decrease was observed in the 3 end organs as the fish grew (Table 1, Fig. 4).

\section{Growth of the sensory epithelia}

A postembryonic increase in the area of the sensory epithelia and in the number of sensory hair cells was

Table 1. Merluccius merluccius. Decrease of density of hair cells in the 3 end organs in relation to fish body length. $a=x$ coefficient; $b=$ slope of growth relationship; SE $b=$ standard error of $b_{i} t=$ Student's $t$-test; $\mathrm{s}=$ significant at $95 \%$ level $_{\text {; }}$ ns $=$ nonsignificant

\begin{tabular}{|c|c|c|c|c|}
\hline \multicolumn{5}{|c|}{ Density of hair cells versus total length of the fish } \\
\hline End organ & $\mathrm{r}^{2}$ & $a$ & $b$ & SE $b$ \\
\hline Saccule & 0.84 & 139.9 & -0.482 & 0.065 \\
\hline Utricle & 0.58 & 136.4 & -0.308 & 0.099 \\
\hline Lagena & 0.56 & 110.9 & -1.912 & 0.044 \\
\hline \multicolumn{5}{|c|}{ Difference in density of hair cells between end organs } \\
\hline & & \multicolumn{2}{|c|}{$t$} & erence \\
\hline \multicolumn{2}{|c|}{ Saccule versus utricle } & \multicolumn{2}{|c|}{-2.16} & $\mathrm{~s}$ \\
\hline \multicolumn{2}{|c|}{ Saccule versus lagena } & \multicolumn{2}{|c|}{-2.29} & $\mathrm{~s}$ \\
\hline \multicolumn{2}{|c|}{ Utricle versus lagena } & \multicolumn{2}{|c|}{-0.77} & ns \\
\hline
\end{tabular}



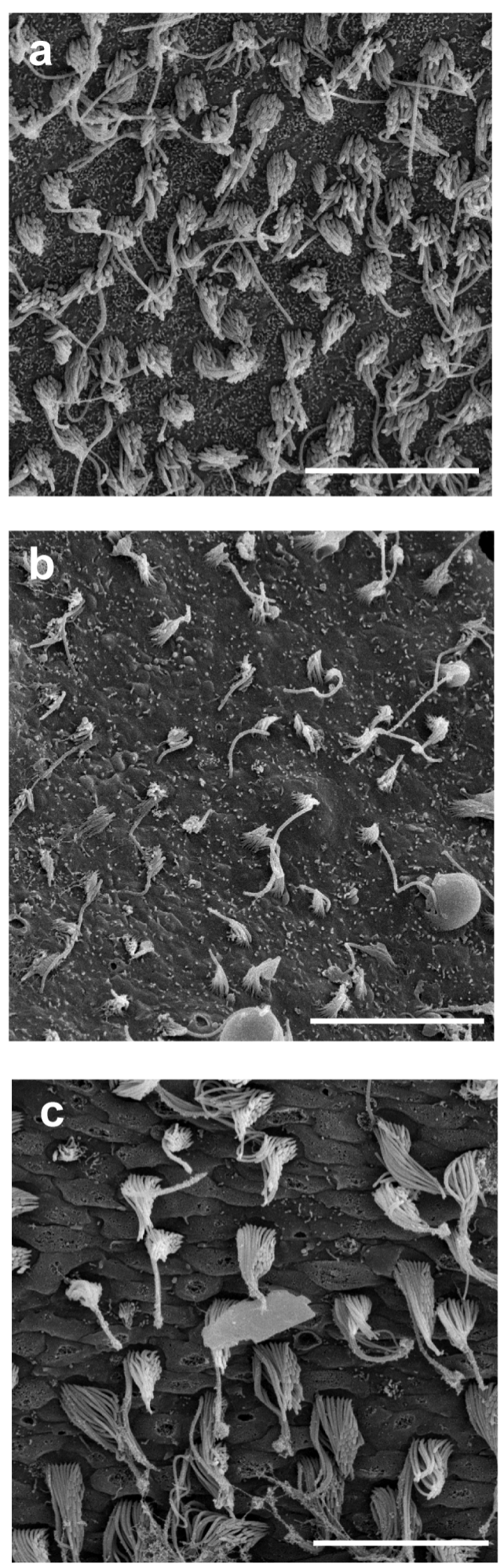

Fig. 3. Merluccius merluccius. Scanning electron micrographs of ciliary bundles of the sensory hair cells from the 3 different end organs of a $50 \mathrm{~mm}$ fish. (a) Nonstriolar zone of the lagena (Region 2 of Fig. 1), (b) nonstriolar zone of the utricle (Region 5 of Fig. 1), (c) peripheral zone of saccule (Region 4 of Fig. 1). Scale bars $=10 \mu \mathrm{m}$

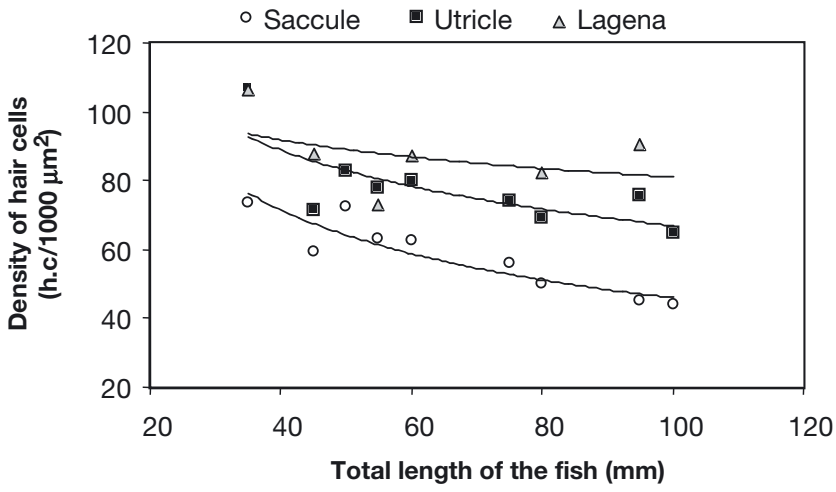

Fig. 4. Merluccius merluccius. Relationship between densities of sensory hair cells (number of hair cells per $1000 \mu^{2}$ ) in each of the otolith end organs for fish of different sizes. Lines are best-fit regressions from a power equation

observed in the 3 end organs (Fig. 5). The growth of the area and the number of hair cells of the saccule shows a positive allometric relationship to fish length. In contrast, the utricle and lagena growth shows an isometric relationship to fish length (Table 2).

In relation to the sensory epithelium area (Fig. 5a), juveniles up to $5 \mathrm{~cm}$ in total length had a utricle that was larger than the saccule. At $35 \mathrm{~mm}$, each utricle was ca. $0.050 \mathrm{~mm}^{2}$ and each saccule was less than $0.036 \mathrm{~mm}^{2}$. After $50 \mathrm{~mm}$, these relationships changed and the area of saccular sensory epithelium became greater than that of the utricle. At $60 \mathrm{~mm}$, each saccule measured ca. $0.13 \mathrm{~mm}^{2}$ and the utricle ca. $0.08 \mathrm{~mm}^{2}$, and at $100 \mathrm{~mm}$, the differences became greater, with each saccule measuring close to $0.70 \mathrm{~mm}^{2}$ and each utricle ca. $0.30 \mathrm{~mm}^{2}$.

The number of hair-cell ciliary bundles also changed with size of the fish (Fig. 5b). Until fish reached

Table 2. Merluccius merluccius. Growth of the sensory epithelia and number of hair cells in the 3 end organs in relation to fish body length. $b=$ slope of growth relationship; SE $b=$ standard error of $b_{;} t=$ Student's $t$-test $;$ +allometry $=$ positive allometry; $\mathrm{s}=$ significant at $95 \%$ level ns $=$ nonsignificant

\begin{tabular}{|c|c|c|c|c|c|}
\hline \multicolumn{6}{|c|}{ Sensory epithelia area versus fish body length } \\
\hline End organ & $\mathrm{r}^{2} \quad b$ & $\mathrm{SE} b$ & $t \quad \mathrm{I}$ & ference & Growth \\
\hline Saccule & 0.923 .132 & 0.268 & 6.92 & $S$ & +allometry \\
\hline Utricle & 0.931 .738 & 0.135 & -2.26 & ns & Isometry \\
\hline Lagena & 0.911 .912 & 0.363 & -0.46 & ns & Isometry \\
\hline \multicolumn{6}{|c|}{ Number of hair cells versus fish body length } \\
\hline End organ & $r^{2}$ & $\mathrm{SE} b$ & $t \quad \mathrm{I}$ & ference & Growth \\
\hline Saccule & 0.942 .635 & 0.219 & 4.91 & S & +allometry \\
\hline Utricle & 0.911 .469 & 0.237 & -3.45 & ns & Isometry \\
\hline Lagena & 0.921 .776 & 0.241 & -1.44 & ns & Isometry \\
\hline
\end{tabular}



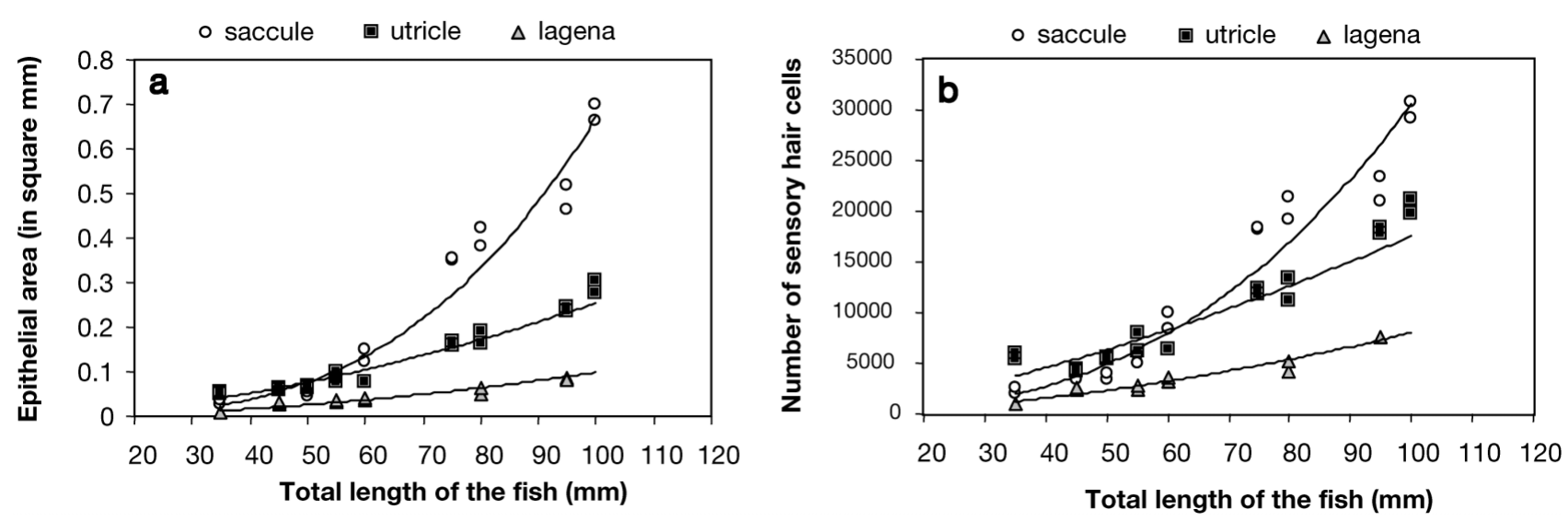

Fig. 5. Merluccius merluccius. End-organ size compared with changes in the length of fish. (a) Epithelial area per end organ, (b) number of hair cells per end organ. Lines are bestfit regressions from a power equation

ca. $55 \mathrm{~mm}$, the utricle had the most sensory cells. At $35 \mathrm{~mm}$, each utricle contained ca. 5500 hair cells and each saccule ca. 2000 cells. After $55 \mathrm{~mm}$, the saccule had the larger number of hair cells. At $60 \mathrm{~mm}$, each saccule had over 8000 hair cells and each utricle no more than 6500 hair cells. The lagena sensory area and hair cell number were lower than in the other 2 end organs at all life stages of the fish.

The percentage of the total sensory epithelium area in each ear from each end organ is shown in Fig. 6a. The saccular epithelium in a $35 \mathrm{~mm}$ specimen represents $30 \%$ of the total sensory area of each ear, whereas the utricle was ca. $55 \%$ and the lagena $15 \%$. At $55 \mathrm{~mm}$, the saccule and utricle are each ca. $40 \%$ of total end organ area, whereas the lagena is $20 \%$. In a $100 \mathrm{~mm}$-long fish, the saccule is $60 \%$ of the total sensory area, whereas the utricle is $30 \%$ of the area and the lagena is $10 \%$. Because the density of hair cells in the lagena and utricle is higher than that for the saccule, the percentage of bundles in the saccule in relation to the total number of hair cells in all of the end organs of an ear is smaller than the percentage of sensory area (Fig. 6b). At $35 \mathrm{~mm}$, only $25 \%$ of cells are in the saccule, but this percentage increases to near $50 \%$ in fish between 60 and $100 \mathrm{~mm}$. In contrast, the percentage of cells in the utricle decreases from $60 \%$ at $35 \mathrm{~mm}$ to less than $40 \%$ at $100 \mathrm{~mm}$. In the lagena, the percentage of hair cells varies between 11 and $25 \%$ of the total.

\section{Otolith area growth and $\mathrm{M}: \mathrm{O}$ ratio changes}

The utricular and lagenar otoliths (lapillus and asteriscus, respectively) grow at a slower rate than does the saccular otolith (sagitta). The saccular otolith is always the largest of the 3 otoliths, and its size increment shows a positive allometric relationship with fish
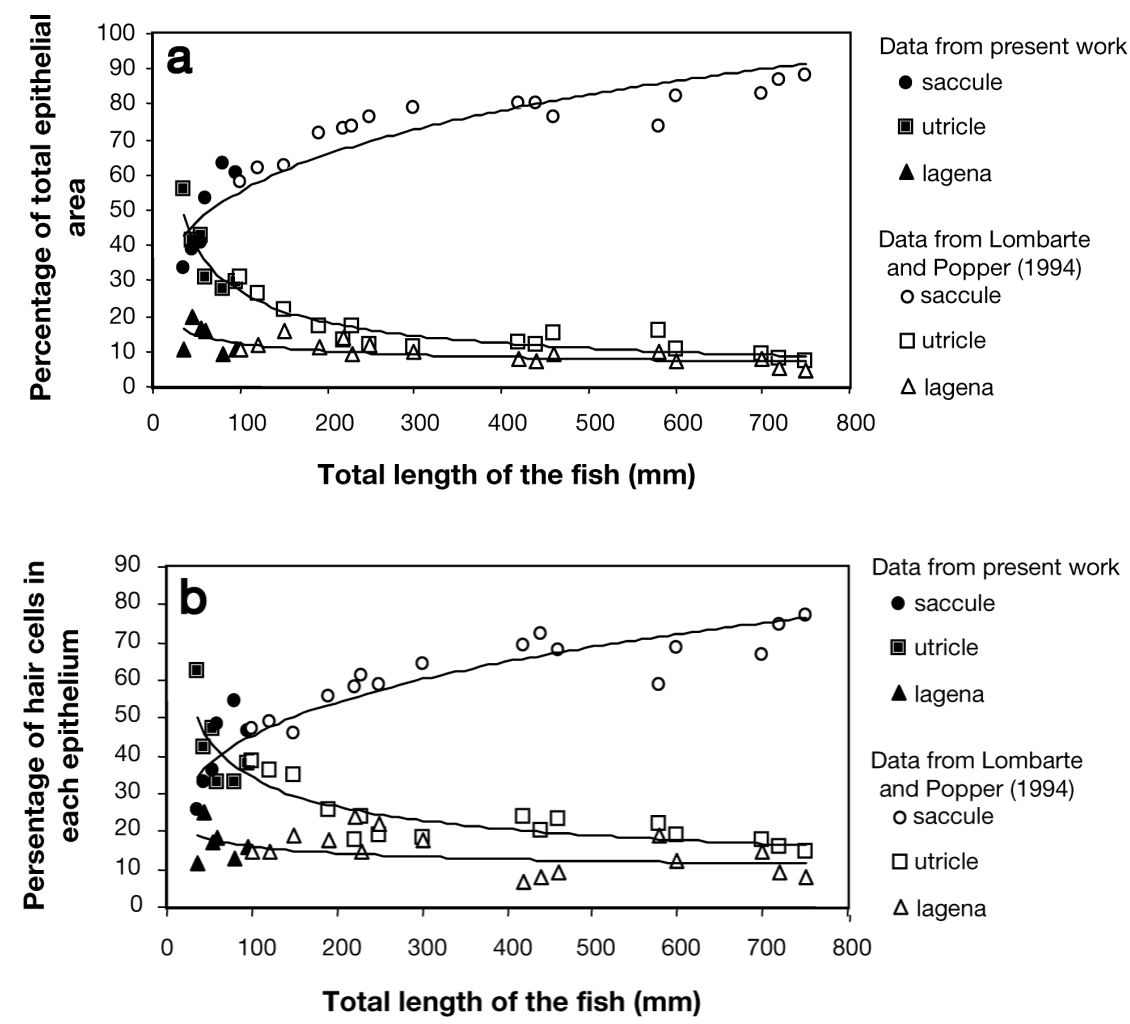

Fig. 6. Merluccius merluccius. Relative sizes and number of hair cells in each otolith organ for different sized fish, expressed as percentage of (a) total end-organ epithelial area from each end organ, (b) total hair cells in 1 ear that are found in each epithelia. Lines are best-fit regressions from a power equation 


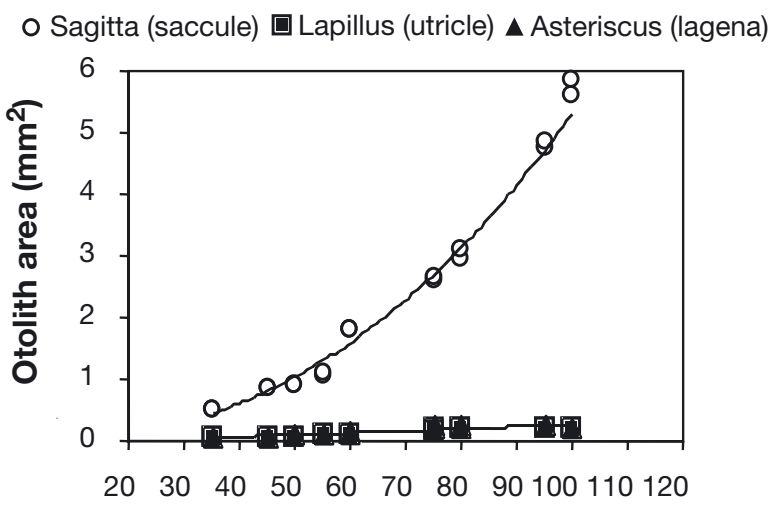

Total length of the fish $(\mathrm{mm})$

Fig. 7. Merluccius merluccius. Otolith size compared with changes in the length of fish. Lines are best-fit regressions from the power equation

growth (Fig. 7). In contrast, the size of the otoliths in the utricle and lagena remains negatively allometric. (Sagitta area: $b=2.357 \pm 0.053, t=4.91, \mathrm{p}<0.001, \mathrm{r}^{2}=$ 0.98 ; lapillus area: $b=1.361 \pm 0.131, t=-5.58, \mathrm{p}<$ $0.001, \mathrm{r}^{2}=0.90$; asteriscus area: $b=1.517 \pm 0.133, t=$ $\left.-4.19, \mathrm{p}<0.001, \mathrm{r}^{2}=0.92\right)$.

The ratio between sensory epithelia area and otolith area (M:O ratio) differed in each end organ (Fig. 8). The higher ratio was found in the utricle (between 0.70 and 1.40) and less in the saccule (between 0.05 and $0.14)$. The lagena showed an intermediate $\mathrm{M}: \mathrm{O}$ ratio (between 0.20 and 0.44).

\section{DISCUSSION}

\section{Importance of morphological changes of inner ear}

The data on the small specimens of Merluccius studied here show the characteristic saccular dual hair-cell pattern that has been reported in adult hake (Lombarte \& Popper 1994), other members of its genus (Lombarte \& Fortuño 1992), and other Gadiformes (Dale 1976, Popper 1980, Popper 1981). The few differences found in the smallest individuals follow the growth trends observed in our study of adult hake. Taken together, the results of the 2 studies show that as hake grow from larval forms to adults, there are continuous changes in the saccular sensory epithelium that includes increases in the proportion of vertically oriented cells and in the area of the caudal portion of the epithelium.

The inversion in the percentage of sensory epithelia area and number of hair cells between the saccule and utricle is coincident with the settlement period that

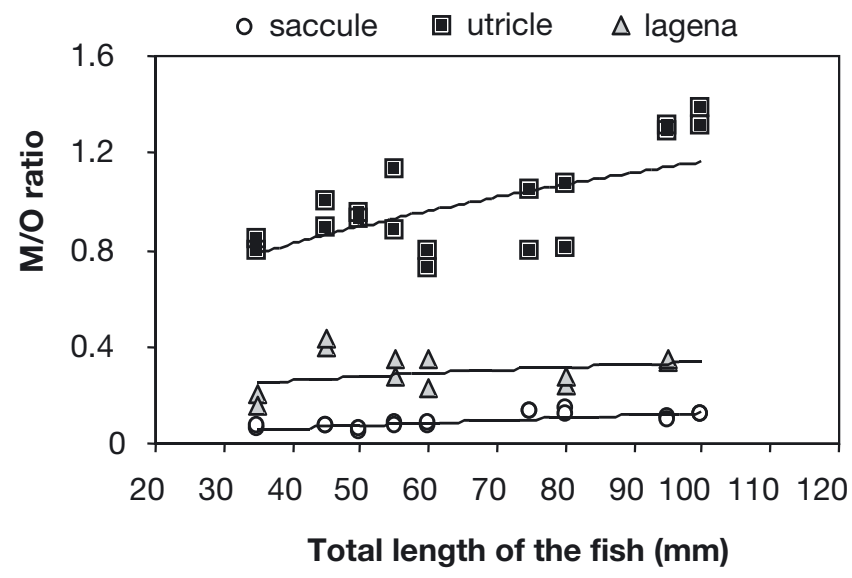

Fig. 8. Merluccius merluccius. Changes of the ratio of the sensory epithelia area versus otolith area that was in contact with sensory epithelia (M:O ratio) in relation to fish length. Lines are best-fit regressions

takes place when most individuals are around $50 \mathrm{~mm}$, during which time the fish in this study become epibenthic. These quantitative changes in the ear could be related to ecological changes. Individuals pass from a pelagic life with zooplanctivorous feeding (related to a passive method to capture prey) to an epibenthic habitat where the hake become specialized in the capture of small mobile and epibenthic crustaceans. If the function of the utricle (with greatest development than the other end organs in the pelagic phase) is basically related to equilibrium, the change could correspond to a decrease in the need to maintain the spatial position in the water column. When the fish become epibenthic and active predators, the development of the saccule, which potentially has an auditory function in this species, could be related to the ability to locate and follow motile preys (Guichet 1995, Bozzano et al. 1997, Bozzano \& Catalan 2002).

A somewhat different correlation may also be possible. Although there are no embryonic studies of development of the ear in any gadiform species, studies on several other species including the oyster toadfish Opsanus tau show that the utricle is the first end organ to develop (Sokolowski \& Popper 1988). If this is the case in hake, it is possible that the change in ecology and behavior of this species is delayed until the saccule is of sufficient size to detect sounds that may be involved in prey capture, and this occurs once the saccule is larger than the utricle.

In contrast to growth patterns of the sensory epithelia of the 3 end organs, the saccular otolith was the largest otolith in all fish greater than $35 \mathrm{~mm}$ in total length. A similar feature was observed in Merluccius merluccius from the Adriatic Sea (Arneri \& MoralesNin 2000). Moreover, the size difference in relation to 
the other 2 otoliths (lapillus and asteriscus) increased with fish growth (see Fig. 8). These differences between otolith growth and sensory epithelia growth implied differences in the M:O ratio.

\section{Other sensory morphological changes during the settlement period}

During the settlement period of Merluccius, there are not only morphometric changes in the inner ear, but also substantial changes in the retinal topography (Bozzano \& Catalan 2002). Bozzano \& Catalan (2002) found that in fish between 40 and $50 \mathrm{~mm}$ in length, the visual axes are directed upward and downward, suggesting a relationship with the location of the fish in the water column and with its pelagic lifestyle. After $50 \mathrm{~mm}$, the fish show a widening of the dorsorostral and ventral fields of best vision, and this may be related to the location of prey (small epibenthic crustaceans) and possible predators (other epibenthic fishes). In the later juvenile and adult phases, measuring between 100 and $800 \mathrm{~mm}$, there is also a correspondence between inner ear and retinal adaptations. The increase in the proportion of rod cells in the retina (Mas-Riera 1991, Bozzano \& Catalán 2002) is parallel to the increase in the proportion of hair cells in the saccule of the inner ear (Lombarte \& Popper 1994) and the increase in the depth range (hake greater than $350 \mathrm{~mm}$ in length live at depths up to $800 \mathrm{~m}$; Recasens et al. 1998) and their higher proportion of high motile prey such as clupeiform and gadiform fishes (Gichet 1995, Bozzano et al. 1997). These specializations become essential to living at depths that have limited light. Thus it appears that the changes in both the eye and inner ear could be correlated to the ecological changes during the period of greatest ecological changes in the life history of $M$. merluccius.

The changes in sensory structures can help explain how the hake could be adapted to the radical changes produced in the transition from pelagic to epibenthic juvenile larvae. These different habitats present different abiotic and biotic challenges, including changes in the hydrodynamic regime and habitat structure (Balon 1986, McCormick 1993). In their initial phases of life, being pelagic is related with life in the water column and feeding on zooplankton, where it is necessary to have good equilibrium. At the same time, these fishes most probably have minimal ability to avoid predators or seek prey.

Finally, this study highlights the importance of research into ontogenetic changes in sensory systems in order to attempt to correlate morphological changes with functional adaptations (Norton et al. 1995). Therefore, the results allow us to avoid phylogenetic inter- ferences, those masked adaptive changes, which could appear when morphological differences between different species are compared (Losos \& Miles 1994).

Acknowledgements. We thank Drs. F. Sardà and J. Lleonart for their invitation to participate in the LLUCET project surveys (UE/ FAIR-CT97-3522). We express our gratitude to the scientific and fishing teams of oceanographic vessel BO 'Garcia del Cid' for their help in the sampling, and especially Dr. A. Bozzano for his valuable comments. We also thank Helen Popper for editing earlier versions of this manuscript.

\section{LITERATURE CITED}

Arneri E, Morales-Nin B (2000) Aspects of the early life history of European hake from the central Adriatic. J Fish Biol 56:1368-1380

Balon EK (1986) Types of feeding in the ontogeny of fishes and the life-history mode. Environ Biol Fish 16:11-24

Blaxter JHS (1988) Sensory performance, behavior and ecology of fish. In: Atema J, Fay RR, Popper AN, Tavolga WN (eds) Sensory biology of aquatic animals. Springer-Verlag, New York, p 203-232

Bozzano A, Catalan IA (2002) Ontogenic changes in the retinal topography of the European hake, Merluccius merluccius: implications for feeding and depth distribution. Mar Biol 141:549-559

Bozzano A, Recasens L, Sartor P (1997) Diet of the European hake Merluccius merluccius (Pisces: Merlucciidae) in the Western Mediterranean (Gulf of Lion). Sci Mar 61:1-8

Cass-Calay LS (2003) The feeding ecology of larval Pacific hake (Merluccius productus) in the California current region: an updated approach using combined OPC/MOCNESS t. Fish Oceanogr 12:34-48

Dale T (1976) The labyrinthin mechanoreceptor organs of the cod Gadus morhua L. (Teleostei: Gadidae). Norw J Zool 24:85-128

Guichet R (1995) The diet of European hake (Merluccius merluccius) in the northern part of the Bay of Biscay. ICES J Mar Sci 52:21-31

Fay RR, Popper AN (2000) Evolution of hearing in vertebrates: the inner ears and processing. Hear Res 149:1-10

Lleonart J (2001) Impact of fishery and environment on hake recruitment in Northwestern Mediterranean. Final Report, EU Contract FAIR CT-97-3522 (1998-2000), Barcelona

Lombarte A, Fortuño JM (1992) Differences in morphological features of the sacculus of the inner ear of two hakes (Merluccius capensis and $M$. paradoxus) inhabits from different depth of sea. J Morphol 213:97-107

Lombarte A, Popper AN (1994) Quantitative analyses of postembryonic hair cell addition in the otolithic end organs of the inner ear of the European hake, Merluccius merluccius (Gadiformes, Teleostei). J Comp Neurol 345:419-428

Lombarte A, Yan HY, Popper AN, Chang JS, Platt C (1993) Damage and regeneration of hair cells in a fish ear following treatment with gentamicin. Hear Res 64:166-174

Losos JB, Miles DB (1994) Adaptation, constraint, and the comparative method: phylogenetic issues and methods. In: Wainwright PC, Reilly SM (eds) Ecological morphology. University of Chicago Press, Chicago, IL, p 42-59

Mas-Riera J (1991) Changes during growth in the retinal structure of three hake species, Merluccius spp. (Teleostei: Gadiformes), in relation to their depth distribution. J Exp Mar Biol Ecol 152:91-104 
Maynou F, Lleonart J, Cartes JE (2003) Seasonal and spatial variability of hake (Merluccius merluccius L.) recruitment in the NW Mediterranean. Fish Res 60:65-78

McCormick MI (1993) Development and changes at settlement in the barbel structure of the reef fish, Upeneus tragula (Mullidae). Environ Biol Fish 37:269-282

Motos I, Alvarez PI, Uriarte A (2000) Distribution pattern of hake Merluccius merluccius (L.) eggs and larvae in relation to environmental conditions in the Bay of Biscay in winter and early spring 1995. Ozeanografika 3: 273-292

Norton SF, Luczkovich JL, Motta PJ (1995) The role of ecomorphological studies in the comparative biology of fishes. Environ Biol Fish 44:287-304

Olivar MP, Sabatés A (1997) Vertical distribution of fish larvae in the NW Mediterranean Sea in spring. Mar Biol 129: 289-300

Olivar MP, Quílez G, Emelianov M (2003) Spatial and temporal distribution and abundance of European hake, Merluccius merluccius, eggs and larvae in the Catalan coast (NW Mediterranean). Fish Res 60:321-331

Popper AN (1980) Scanning electron microscopic investiga-

Editorial responsibility: Otto Kinne (Editor),

Oldendorf/Luhe, Germany tions study of the sacculus and lagena in several deep-sea dishes. Am J Anat 157:115-136

Popper AN (1981) Comparative scanning electron microscopic investigations of the sensory epithelia in the teleost sacculus and lagena. J Comp Neurol 200:357-374

Popper AN, Coombs S (1982) The morphology and evolution of the ear in actinopterygian fishes. Am Zool 22:311-328

Popper AN, Fay RR, Platt C, Sand O (2003) Sound detection mechanisms and capabilities of teleost fishes. In: Collin SP, Marshall NJ (eds) Sensory processing in aquatic environments. Springer-Verlag, New York, p 3-38

Recasens L, Lombarte A, Morales-Nin B, Torres G (1998) Spatiotemporal variation in the population structure of the European hake in the NW Mediterranean. J Fish Biol 53: 387-401

Ricklefs RE, Miles DB (1994) Ecological and evolutionary inferences from morphology. An ecological perspective. In: Wainwright PC, Reilly SM (eds) Ecological morphology. University of Chicago Press, Chicago, IL, p 13-41

Sokolowski B, Popper AN (1988) Transmission electron microscopic study of the saccule in the embryonic, larval, and adult toadfish, Opsanus tau. J Morphol 198:49-69

Submitted: July 21, 2003; Accepted: November 18, 2003 Proofs received from author(s): February 2, 2004 